\title{
ADMINISTRASI TATA KELOLA DALAM PENDIDIKAN
}

\author{
Irma Irma ${ }^{1}$, Andi $\mathrm{Arsi}^{2}$, Muhammad Arsyam ${ }^{3}$
}

\author{
${ }^{1}$ Sekolah Tinggi Agama Islam (STAI) Darul Dakwah Wal-Irsyad (DDI) Kota Makassar, Indonesia \\ Email: irmhaimmha1234@gmail.com \\ ${ }^{2}$ Sekolah Tinggi Agama Islam (STAI) Darul Dakwah Wal-Irsyad (DDI) Kota Makassar, Indonesia \\ Email: andiarsi792@gmail.com \\ ${ }^{3}$ Sekolah Tinggi Agama Islam (STAI) Darul Dakwah Wal-Irsyad (DDI) Kota Makassar, Indonesia \\ Email: arsyam0505@gmail.com
}

\begin{abstract}
ABSTRAK
Administrasi Pendidikan dalam Profesi Keguruan merupakan kegiatan pendidikan untuk mengembangkan kemampuan dalam bidang administrasi. ilmu pengetahuan, teori belajar dan ketrampilan yang dilaksanakan bertujuan jangka panjang yaitu agar tenaga administrasi, manajemen maupu mengembangkan ilmu yang telah dipelajari dan dipraktekkan di sekolah. Kata "administrasi” berasal dari bahasa latin yang terdiri atas kata ad dan ministrare. Kata ad mempunyai arti yang sama dengan kata todalam bahasa inggris, yang berarti "ke" atau "kepada". Dan ministrare sama artinya dengan kata to serve atau to conduct yang berarti "melayani”, "membantu”, atau mengarahkan”. Dalam bahasa inggris to administer berarti pula "mengatur”, "memelihara” (to look after), dan "mengarahkan”. Jadi, kata "administrasi” dapat diartikan sebagai suatu kegiatan atau usaha untuk membantu, melayani, mengarahkan, atau mengatur semua kegiatan di dalam mencapai suatu tujuan.
\end{abstract}

\section{Kata Kunci: Administrasi, Tata Kelola, Dalam Pendidikan}

\section{A. PENDAHULUAN}

Secara etimologis istilah administrasi berasal dari bahasa inggris dari kata "Administration” yang bentuk administratifnya adalah “to administer”. Dalam Oxford Advance Leaner’s Dictionari of Current English (1974), kata to administer diartikan sebagai to manage (mengelola) atau to direct (menggerakkan). Kata adminstratie yang mempunyai pengertian yang mencakup stelselmatige verkrijging en verwerking van gegeven (tata usaha), bestuur (manajemen dari kegiatan-kegiatan organisasi), dan beheer(manajemen dari sumber daya,seperti financial, personel, gudang). Istilah pengertian dan hakikat administrasi di Indonesia pada mulanya berasal dari Eropa Barat atau Eropa Konstinental melalui penjajahan Belanda (Belanda merupakan salah satu negara Eropa Konstinental).

Administrasi Pendidikan Dalam Profesi Keguruan merupakan kegiatan pendidikan untuk mengembangkan kemampuan dalam bidang administrasi. Namun secara singkatnya, administrasi pendidikan itu ialah pembinaan, pengawasan, dan pelaksanaan dari segala sesuatu yang berhubungan dengan unsurunsur sekolah. 


\section{B. PEMBAHASAN}

\section{Administrasi Tata Kelola Dalam Pendidikan}

Tata kelola sekolah laksana dapur pada sebuah rumah. Peran dapur seolah-olah tidak tampak. Namun, ketika hidangan tidak tersedia pada waktunya, penghuni rumah ingat pada dapur dan ingat kepada siapa yang memasak di dapur.Sebagai aktivitas sadar dan terencana, pendidikan sejatinya memerlukan ketertiban dalam segala aspeknya. Pada tataran paraktis kebutuhan semacam ini tersusun dengan baik dalam sistem dan tata kelola pendidikan. Melalui tata laksana elemen yang mengelola dan menjalankan proses pendidikan akan dengan mudah menjalankan tugas dan fungsinya.

Tata kelola atau tata laksana merupakan bagian tak terpisahkan dari pendidikan. Tata kelola pendidikan sendiri memiliki hubungan yang sangat erat dengan administrasi. Bahkan proses pendidikan dan tata kelolanya sangat tergantung pada administrasi. Pada pendidikan, administrasi bukan sekadar penunjang, tapi juga penopang utama penyelenggarannya, terutama dalam mewujudkan ketertiban tata kelola pendidikan itu sendiri.

\section{Pengertian Administrasi}

Administrasi sebagai suatu kegiatan bersama terdapat dimana-mana selama ada manusia yang hidup dan bekerjasama dalam kelompok. Secara teoritik, administrasi adalah melayani secara intensif, sedangkan secara etimologis administrasi dalam Bahasa Inggris “administer" yaitu kombinasi dari kata latin yang terdiri dari kata AD dan MINSTRARE yang berarti "to serve": melayani, membantu dan memenuhi.Jadi, secara etimologis administrasi adalah melayani secara intensif.

Administrasi sekolah merupakan representasi serial proses kerja yang dilaksanakan di sekolah, sedangkan tata kelola merupakan bagian darinya. Dengan demikian, tata kelola merupakan bagian tak terpisahkan dari pendidikan. Tata kelola pendidikan sendiri memiliki hubungan yang sangat erat dengan administrasi. Bahkan proses pendidikan dan tata kelolanya sangat tergantung pada administrasi. Dengan demikian, administrasi bukan sekadar penunjang, tapi juga penopang utama penyelenggaran pendidikan, terutama dalam mewujudkan ketertiban tata kelola atau tata laksana pendidikan. 
Menurut Sudarwan Danim Tata Laksana adalah kegiatan atau usaha untuk membantu, melayani, memudahkan atau mengatur semua kegiatan dalam mencapai suatu tujuan.Definisi ini erat kaitannya dengan administrasi sebagai sebuah instrumen oranisasi dan proses pendidikan dalam berbagai level dan cakupannya.Ini bermakna, semua kegiatan di sekolah harus diatur sedemikian rupa agar memililiki ketertiban tertentu, sehingga pelaksanaan pendidikan berjalan dengan baik dan proses pembelajaran berjalan dengan lancar. Jadi, tata kelola atau tata laksana pendidikan adalah kegiatan atau usaha untuk membantu, melayani, memudahkan atau mengatur semua kegiatan pendidikan dalam mencapai tujuan pendidikan.

\section{Urgensi dan Fungsi Administrasi Tata Kelola}

Sebagai sebuah instrumen pendidikan, administrasi tata kelola atau tata laksana pendidikan memiliki ruang lingkup tersendiri. Dengan demikian, administrasi tata kelola pendidikan tersusun dengan baik dan dapat dipertanggungjawabkan, baik ke internal organisasi maupun ke eksternal organisasi. Di sini staf tata kelola sebagai elemen atau pelaku utama memiliki tugas penting dalam berbagai bentuk kegiatannya; dari urusan internal hingga urusan eksternal sekolah.

Menurut G. Terry (1982) dalam Sudarwan (2010: 54) mengemukakan kegiatan staf tata kelola atau tata laksana yaitu: 1. Mengetik, 2. Menghitung, 3. Memeriksa, 4. Menyimpan, 5. Menelpon, 6. Menggadakan, 7. Mengirim surat, 8. Dan lain-lain.Dalam pandangan lain, tata kelola atau tata laksana memiliki kegiatan khas termasuk menggolongkan atau memisah berbagai data penting seputar proses pendidikan.

Mil dan Standingford (1982) menyebutkan delapan kegiatan staf tata kelola atau tata laksana, yaitu : Pertama, menulis surat, Kedua, membaca, Tiga, menyalin (menggandakan), Empat, menghitung, Lima, memeriksa, Enam, memilah atau menggolongkan dan menyatukan, Tujuh, menyimpan dan menyusun indeks, Delapan, melakukan komunikasi.

Senada dengan ini, The Lian Gie (2000) berpendapat bahwa tenaga tata kelola atau tata laksana memiliki tiga peranan yaitu:

1) Melayani pelaksanaan pekerjaan-pekerjaan operatif untuk mencapai tujuan dari suatu organisasi

2) Menyediakan keterangan-keterangan bagi pucuk pimpinan organisasi itu untuk membuat keputusan atau melakukan tindakan yang tepat, dan

3) Membantu kelancaran perkembangan organisasi sebagai suatu keseluruhan. Di lingkungan sekolah staf tata kelola atau tata laksana bersifat multifungsi. 
Mereka dituntut menjalankan roda sekolah, staf tata kelola atau tata laksana sekolah harus mampu memberikan dukungan secara efektif dan efesien terutama berkaitan dengan tugas mereka sebagai:

1) Pelaksana urusan persuratan dan pengarsipan (kesekretariatan),

2) Pelaksana urusan kepegawaian (guru dan tenaga kependidikan lainnya),

3) Pelaksana urusan keuangan (pembiayaan sekolah),

4) Pelaksana urusan kurikulum dan pembelajaran,

5) Pelaksana urusan kesiswaan,

6) Pelaksana urusan sarana dan prasarana,

7) Pelaksana urusan hubungan sekolah dengan masyarakat, dan

8) Pelaksana tugas lainnya.

Menurut Sudarwan (2010: 55), secara operasional tata kelola atau tata laksana sekolah berfungsi membantu administrator atau kepala sekolah dalam kegiatan-kegiatan:

1) Administrasi (urusan surat menyurat, ketatausahaan) sekolah yang berkaitan dengan pembelajaran;

2) Kepegawaian, baik pendidik maupun tenaga kependidikan yang bertugas di sekolah;

3) Pengelola kekuangan sekolah;

4) Mengelola perlengkapan atau logistik sekolah;

5) Mengelola kesekretariatan dan kesiswaan;

6) Mengantarkan surat keluar;

7) Memelihara dan memperbaiki fasilitas sekolah berupa bangunan, kelistrikan, dan peralatan praktik;

8) Dan lain-lain.

Standar layanan sekolah sendiri sesungguhnya merupakan bagian dari standar nasional pendidikan. Standar nasional pendidikan yang dimaksud, yaitu:

1) Standar isi,

2) Standar proses,

3) Standar kompetensi lulusan;

4) Standar pendidik dan tenaga kependidikan,

5) Standar sarana dan prasarana, 
6) Standar pengelolaan,

7) Standar pembiayaan, dan

8) Standar penilaian pendidikan

\section{Standar Kompetensi Tata Kelola}

Staf tata kelola atau tata laksana harus memiliki kompetensi tertentu. Keberadaan tata laksana sekolah lazimnya disebut tata usaha sekolah sangat penting terutama dalam kerangka mendukung proses pembelajaran khususnya atau pendidikan umumnya. Berdasarkan skema berstandar kompetensi, maka tugas tugas dan fungsi staf tata kelola atau tata laksana sekolah di jenjang pendidikan dasar dan menengah idealnya tidak boleh dilakukan oleh guru SD, SMP dan SMA atau yang sederajat. Pekerjaannya bersifat administratif yang tunduk pada aturan yang bersifar khusus, merupakan pekerjaan pelayanan untuk kelancaran proses pembelajaran. Mereka memerlukan kemampuan dan keterlampilan yang berbeda dengan kompetensi yang disyaratkan untuk pendidik.

Seperti dikemukakan oleh Wukir Ragil (2008), sesuai aturan kepegawaian, tugas staf tata kelola atau tata laksana sekolah pada jenjang pendidikan dasar dan menengah tidak boleh dirangkap oleh tenaga fungsional yang lain. Keberadaan staf tata kelola atau disebut juga tata usaha merupakan bagian integral dari sub system lain. Sub system tersebut, antara laian meliputi siswa, guru, administrator atau kepala sekolah, laboran, pustakawan, instruktur, bendahara sekolah, penjaga sekolah dan lain-lain.Sub system ini tidak berada pada konteks yang kosong, karena mereka baik bersama-sama maupun individual mendayagunakan buku pelajaran, kurikulum, masyarakat, lingkungan sekolah, kebijakan pemerintah, aturan/tata tertib sekolah, dan lain-lain.

Di samping itu, yang tidak kalah penting adalah prinsip fokus pada penyelearasan kewengangan dan tanggungjawab sebagai kunci peningkatan kinerja. Tenaga adminsitrasi sekolah di samping memenuhi standar kualifikasi, juga diperlukan kompetensi untuk mengimbangi kualifikasi dan kompetensi yang dimiliki oleh guru dan tenaga kependidikan lainnnya.Standar kualifikasi yang harus dipenuhi meliputi kualifikais pendidikan dan sertifikasi kepala staf tata laksana sekolah (khusus bagi kepala administrasi staf tata laksana seklolah) yang masing-masing berbeda untuk setiap jenjang pendidikan. Staf tata laksana paling rendah yaitu bagi tenaga atau petugas pelayanan khusus atau tukang kebun, penjaga sekolah, penjaga kebersihan, 
pengemudi, dan pesuruh. Standar kompetensi dimaksud meliputi: kepribadian, sosial, teknis dan manajerial.

Sesuai dengan Peraturan Menteri Pendidikan Nasional RI Nomor 24 Tahun 2008, kompetensi yang harus dipenuhi oleh staf tata usaha atau staf administrasi sekolah disajikan sebagai berikut:

Pertama, Kompetensi kepribadian meliputi memiliki integritas dan akhlak mulia, etos kerja, pengendalian diri, percaya diri, fleksibel, ketelitian, kedisiplinan, kreatif, inovatif dan tanggungjawab.

Kedua, Kompetensi sosial meliputi kemampuan bekerja dalam tim, pelayanan prima, kesadaran brorganisasi,berkomunikasi efektif dan membangun hubungan kerja.

Ketiga, Kompetensi teknis meliputi kemampuan melaksanakan administrasi kepagawaian, keuangan, sarana-prasarana, hubungan sekolah dengan masyarakat, persuratan dan pengarsipan, administrasi kesiswaan, adminitrasi kurikulum, administrasi layanan khusus dan penerapan teknologi informasi dan komunikasi.

Keempat, Kompetensi manajerial (khusus bagi kepala staf tatalaksana sekolah) meliputi kemampuan mendukung pengelolaan standar nasional pendidikan, menyusun program dan laporan kerja, mengorganisasikan staf, mengembangn staf, mengambil keputusan, menciptakan iklim kerja yang kondusif, mengoptimalkan pemanfaatan sumber daya, membina staf, mengelola konflik dan menyusun laporan. 


\section{KESIMPULAN}

Seluruh sub system dalam adnimistrasi tata kelolah tersebut sangat berperan dan saling memengaruhi sehingga proses pembelajaran dapat berlangsung sesuai dengan rencana yang telah disusun. Atas dasar itu, tujuan pendidikan dan pembelajaran dapat dicapai dan dampaknya bisa dirasakan.Karena keberadaan staf tata kelola atau tata kelola (tata usaha) juga sangat penting dalam mencapai tujuan pendidikan, telah dietapkan Peraturan Menteri Pendidikan Nasional RI Nomor 24 Tahun 2008 tanggal 11 Juni 2008 Tentang Staf Administrasi Sekolah.Penentuan standar ini wajib dipenuhi agar dapat mengimbangi pelayanan yang dilakukan oleh kepala sekolah, guru dan staf lainnya bagi terselenggaranya proses pendidikan dan pembelajaran. 


\section{DAFTAR PUSTAKA}

Janna, N. M., A., kurnia, A. d., \& Arsyam, M. (2021, January 14). Administrasi Keuangan Dalam Pendidikan. https://doi.org/10.31219/osf.io/hmvcf

Neta, Y. (2014). Model Tata Kelola Administrasi Pemerintahan Yang Baik di Daerah Otonom Baru. FIAT JUSTISIA: Jurnal Ilmu Hukum, 6(2).

Arsyam, M. (2021). BAHAN AJAR ADMINISTRASI PENDIDIKAN.

Hadijaya, Y. (2012). Administrasi pendidikan.

Hardiansyah, H., \& Fahmi, A. (2018, September). Strategi Tata Kelola Administrasi Pada Perguruan Tinggi

Berbasis Electronic Records. In Prosiding Seminar Nasional Lembaga Penelitian Dan Pendidikan (LPP) Mandala (pp. 246-250).

Makmur, Z., Arsyam, M., \& Alwi, A. M. S. (2020). Strategi Komunikasi Pembelajaran Di Rumah Dalam Lingkungan Keluarga Masa Pandemi. KOMUNIDA: Media Komunikasi dan Dakwah, 10(02), 231241.

Kadir, A. (2013). Tata Kelola Perguruan Tinggi di Era ITC. Shautut Tarbiyah, 19(1), 66-83.

Depertemen Agama RI, Al-Quran dan Terjemahnya, (Bandung: PT. Syaamil Cipta Media)

Afriansyah, H. (2019). Administrasi Peserta Didik.

Arsyam, M. (2020). Manajemen pendidikan islam.

Sapada, A. O., \& Arsyam, M. (2020). Ilmu Pengetahuan dan Teknologi Menurut Pandangan Islam.

Zakirah, Z., Jumliadi, J., Arsyam, M., Herianto, H., Rusli, M., \& Alwi, A. M. Implementation of The Islamic Local Regulations in Bulukumba Regency.

Zakirah, Z., Arsyam, M., HERIANTO, H., \& Umar, K. (2020, December 20). PENDIDIKAN DASAR $\begin{array}{llllllll}(\mathrm{KUTTAB}) & \text { MASA DAULAH } & \text { ABBASIYAH } & (132-232 & \mathrm{H} & / & 750-847 & \mathrm{M}) \text {. }\end{array}$ https://doi.org/10.31219/osf.io/7t8bs

Jumliadi, J., Zakirah, Z., Arsyam, M., Alwi, A. M. S., \& Fadhil, M. PEMBELAJARAN DIRUMAH DALAM LINGKUNGAN KELUARGA DI TENGAH PANDEMI COVID 19.

HERIANTO, H. (2020). Pengaruh Kesehatan Mental, Keaktifan Berorganisasi Dan Prestasi Akademikterhadap Tingkat Pemahaman Moderasi Beragama.

Kristiawan, M., \& Asvio, N. (2018). Pengelolaan Administrasi Madrasah Tsanawiyah Negeri Dalam

Meningkatkan Kualitas Pendidikan Madrasah. Kelola: Jurnal Manajemen Pendidikan, 5(1), 86-95. 